\title{
О. О. Бобринський як лідер Об'єднаного дворянства
}

Чернікова Н. С.

Дніпровський державний аграрно-економічний університет

Проаналізовано функціонування всеросійської дворянської суспільно-політичної організації Об'єднаного дворянства під головуванням графа О. О. Бобринського; окреслено його роль у розробці організаційних засад та координуванні напрямків ііі діяльності протягом 1906-1912 pp.

Ключові слова: О. О. Бобринський; 3'їзд уповноважених дворянських громад; Об'єднане дворянство; аграрна реформа; місцеве управління

Проанализировано функционирование всероссийской дворянской общественно-политической организации Объединенного дворянства под председательством графа А. А. Бобринского; очерчена его роль в разработке организационных основ и координации направлений ее деятельности на протяжении 1906-1912 гг.

Ключевые слова: А. А. Бобринский; Съезд уполномоченных дворянских обществ; Объединенное дворянство; аграрная реформа; местное управление

The article considers the functioning of the All-Russian noble socio-political organization of the United nobility under the chairmanship of Count O. Bobrynskiy; is defined his role in the development of organizational principles and coordination of its activities during 1906-1912.

The revolutionary events of 1905, the formation of parliamentarism in Russia actualized in the aristocratic environment the question of creating a strong cell to protect the rights of the class. In 1906, at the initiative of the conservative nobility leaders, the Congress of Authorized Aristocratic Communities - the All-Russian noble organization - was organized. Count O. Bobrynskiy was the Chairman of the United Nobility (the UN) from 1906 to 1912. As a leader, he managed to focus in the hands of the UN leadership - the Permanent Council - significant powers to overcome the disu-nity of provincial leaders, unite the nobility to develop their own political strategy. O. Bobrynskiy, on behalf of the UN, supported the First Duma dissolution and made efforts to develop a new draft electoral law, that assumed the formation of a powerful noble and landowning representation in the parliament. With the support of the UN, the government of P. Stolypin carried out the famous «Third-June coup» of 1907 and the introduction of a new electoral law based on a noble project. As a result, the leaders of the $\mathrm{UN}$, including O. Bobrynskiy, received the desired leverage of political influence on state policy through the parliamentary structures of power.

The direction of O. Bobrynskiy's (and the UN in general) activities in $1907-$ 1911 was due to political dissonance with P. Stolypin through a government project of local government reforms, which greatly restricted the rights and privileges of the local nobility. Thus, their new political tactics envisaged the elaboration of a common line of political behavior for its defending by noble representatives in the Duma. As a result, the government reform of local government was failed.

Keywords: O. O. Bobrynskiy; The Congress of authorized noble communities; the United nobility; agrarian reform; local governance 
Сучасна Україна переживає складний період формування демократичної правової держави, що характеризується різноманіттям політичних партій та угруповань, становленням різних політичних сил та ідеологій в умовах загострення соціальних проблем в українському суспільстві. У зв'язку із цим неоціненним $є$ історичний досвід дослідження такого ж складного й суперечливого періоду в історії Російської імперії, як перше десятиліття XX століття: час становлення російського парламентаризму, протиборства різноманітних політичних і соціальних сил із метою участі у політичному житті та проведення державного реформування. На особливу увагу заслуговує дослідження діяльності О. Бобринського як ідейного та організаційного лідера Об'єднаного дворянства - суспільно-політичної організації, що здійснювала вплив на напрямки внутрішньої політики Російської імперії.

На сучасному етапі комплексне дослідження історії функціонування Об'єднаного дворянства залишається відкритою дослідницькою проблемою. Процеси політизації помісного дворянства крізь призму трансформації соціальної поведінки стану на початку XX ст. знайшли відображення у дисертації російської дослідниці К. Барінової [3]. Стаття А. П. Бородіна [4] присвячена з'ясуванню місця ОД у проведенні аграрної реформи. У монографіях радянських істориків - А. Я. Авреха [1; 2], В. С.Дякіна [8], Ю. Б. Соловйова $[20 ; 21]$ функціонування 3'їзду УДГ періоду головування О. Бобринського розглянуто в контексті взаємовідносин самодержавства, уряду та дворянства в цілому. Суспільно-політичній діяльності графа присвячено дисертаційне дослідження Н. С. Чернікової [23].

У статті використані архівні матеріали - промови, проекти О. Бобринського $[9 ; 10 ; 11 ; 19]$, його щоденникові записи [6], публікації періодичних видань [5], що окреслюють його діяльність в ОД. Значна увага приділена аналізу протоколів засідань 3'їзду УДГ $[13 ; 14]$, установчих документів [18; 22] та постанов Постійної ради $[7 ; 15 ; 16 ; 17]$ періоду головування О. Бобринського.

Революційні події 1905 р., скликання парламенту за булигінським проектом актуалізували в дворянському середовищі питання про необхідність створення міцного осередку з метою захисту станових прав. Наприкінці квітня 1906 р. О. Бобринський та інші політично активні представники консервативного дворянства К. Ф. Головін, С. С. Бехтєєв, О. О. Кірєєв, В. І. Гурко, С. Ф. Шарапов, О. С. Стишинський - взяли участь у роботі Підготовчої комісії 
3 питань скликання нової всеросійської дворянської організації [13, с. 27]. За задумом організаторів, проектований 3'їзд уповноважених дворянських громад (далі - УДГ) мав стати провідним осередком консервативного табору із вироблення лінії політичної поведінки. Після визначення учасниками кола основних завдань майбутньої організації були утворені відповідні комісії; О. Бобринський увійшов відразу до двох - політичної та зі складання імператорської адреси [13, с. 31, 32].

Завдяки злагодженій діяльності організаторів вже 21 травня 1906 р. у Санкт-Петербурзі був скликаний I з'їзд УДГ за участю 114 представників від 29 дворянських громад, що отримав у сучасників назву Об'єднане дворянство (далі - ОД). О. Бобринський та інші члени підготовчих комісій, найбільш відомі дворянські діячі й сановники з урядових кіл, губернські й повітові проводирі були запрошені з правом дорадчого голосу [13, с. 4446]. Вже на першому засіданні О. Бобринський був обраний головою ОД: його кандидатура була підтримана голосами 24 губерній, тоді як інші кандидати, відомі дворянські проводирі князь П. М. Трубецькой і В. В. Гудович, отримали лише 3 і 1 голос відповідно. Результати голосування стали дещо несподіваними, але об'єктивно обгрунтованими; делегати закидали губернським проводирям бездіяльність напередодні скликання. Дійсно, П.Трубецькой, побоюючись звинувачень у зазіханні на царські повноваження і порушення статусу дворянських громад, затягував зі скликанням з'їзду. В. Гудовичу ж нічого не залишалося, як відзначити, що якщо можна було вибрати когось із запрошених, то лише графа О. Бобринського [13, с. 44].

Першочерговим питанням, винесеним О. Бобринським на порядок денний, стало обговорення проекту статуту організації, що проходило в умовах активної дискусії. Частина делегатів виступала проти втручання в урядову політику, тому негативно сприйняла формулювання мети З'їду УДГ: об'єднання дворянства «для обговорення і проведення в життя питань інтересу загальнодержавного, а звідси і станового» [13, с. 56]. До того ж губернські проводирі дворянства побоювалися втратити авторитетність і лідерство в місцевих дворянських громадах, що викликало заперечення О. Бобринського. На засіданні від 23 травня 1906 р. він відзначив: «Авторитетність не може виражатися групою осіб: вона належить усьому стану дворян, що обрали цю групу, i, якщо ми надамо їм особисту відповідальність, буде втрачена всяка сила авторитетності» 
$[13$, c. 56]. Проте вже на II з'їзді Олексій Олександрович здійснив крок назустріч дворянським ватажкам. Він пояснив, що попередня редакція статуту була викликана неприйняттям частиною губернських проводирів ідеї об'єднання дворянства і запропонував внести поправку, за якою вони отримували право дорадчого голосу [13, с. 252-253].

Зазначимо, що статут ОД закріплював за О. Бобринським як головою значне коло повноважень. До його компетенції входило введення поголівного балотування при розгляді другорядних питань, не вдаючись до основної системи голосування по губерніях; висвітлення в пресі лише тих постанов, які він особисто вважав за потрібне; запрошення компетентних осіб при розгляді певних питань без права голосу. До того ж він автоматично очолював і виконавчий орган - Постійну раду, члени якої займалася підготовкою доповідей напередодні з'їдів, тобто фактично визначали та координували спрямованість організації. За часів головування О. Бобринського з'їзди скликалися Постійною радою щороку (прецедент II позачерговий з'їзд). До кола обов’язків керівництва також входили зносини з дворянськими громадами, урядовими колами. Про результати роботи ОД голова доповідав Миколі II особисто [18, с. 147$]$.

Зосередження в руках голови ОД та членів Постійної ради значних повноважень, політичний характер організації неодноразово викликали протидію дворянських делегатів. Наприклад, представник Псковського дворянства О. М. Брянчанинов на засіданні 20 березня 1907 р. заявив, що не вважає за можливе брати участь у виробленні рішень із політичних і загальнодержавних питань. Він засудив дії О. Бобринського, вважаючи, що об’єднання дворянства можливе не на політичному, а на суто корпоративному грунті $[16$, с. 522-523]. Це спонукало голову ОД виступити з полум'яною промовою, що фактично поставила крапку у дискусії навколо цього питання. Вона була відкрито спрямована проти тих проводирів дворянства, які запевняли, що дворянство як стан є явище віджите, а діяльність Постійної ради «принижує гідність» зборів губернських проводирів і депутатів дворянства та зводить призначення губернського проводиря нанівець [13, с. 341].

О. Бобринський відзначив, що проводирі виступали проти самостійності дій ОД та його керівництва й відстоювали ідею перетворення останніх на бюро для підготовки доповідей на губернські дворянські збори [13, с. 342]. На його думку, коло завдань, що мали вирішувати збори проводирів і депутатів, мало 
локальний характер і обмежувалось суто нестатками певної губерніі, тому в справі загального єднання й інтересів російського дворянства про депутатські збори не могло бути і мови. Він справедливо закидав проводирям відсутність єдності, що унеможливлювало перетворення останніх на осередки дворянських об’єднань. Єдиною можливою поступкою граф вважав зміну керівного складу ОД і категорично висловився проти зменшення повноважень Постійної ради, в яких вбачав запоруку ефективної діяльності організації. «На шлях примирення ми згодні, - говорив він, - але ... об'єднання не є колінопреклоніння!» [13, с. 343]. Тож О. Бобринському вдалось відстояти політичну спрямованість та означені у статуті повноваження керівництва ОД, що остаточно був затверджений учасниками та Міністерством внутрішніх справ у 1907 р. [22].

Першочерговим практичним завданням I з'їзду УДГ О. Бобринський вважав затвердження учасниками проекту аграрної реформи, розробленої Постійною радою, з подальшим втіленням в урядовій політиці Росії. Зазначимо, що проведення комплексного аграрного реформування з урахуванням нових суспільно-політичних та економічних реалій становило одну з найважливіших потреб селянства й помісного дворянства - як двох земельних станів Росії. Урядовий законопроект про «примусове відчуження» частини поміщицьких земель на користь селян, запропонований у 1905 р. М. М. Кутлером, викликав невдоволення О. Бобринського та частини помісного дворянства: «Тепер бажають в особи, яка купила землю на трудові заощадження, - говорив він, - насильно відняти частину... і віддати iï сусіду-селянину» [19, арк. 6-7].

Обговорення внесеного О. Бобринським на порядок денний проекту аграрної реформи відбувалось в умовах палкої дискусії: у зв'язку з новим спалахом селянських виступів навесні 1906 р. частина дворян була налаштована на підтримку урядової пропозиції. Проте голова з'їзду закликав присутніх до непохитності у відстоюванні дворянських прав на земельну власність та виступив із категоричним осудом примусового відчуження землі. На його думку, відновлення міцних економічних та соціокультурних зв'язків із селянством було можливе лише на приватновласницькому грунті [13, c. 97-98]. Він закликав від імені дворянського стану вказати уряду альтернативні шляхи вирішення аграр-ного питання й запевняв в ефективності такого способу впливу на правлячі кола з боку панівного стану держави [1, с. 34]. 
У проекті Постійної ради пропонувалось два основні шляхи поліпшення економічного становища селян. По-перше, вихід вбачався у використанні інтенсивних методів господарювання на селі, запровадженні раціонального використання наявної надільної площі в населених пунктах. Інтенсифікація передбачала використання багатопільної землеробської системи з глибокою обробкою грунту і широким застосуванням добрив, а також перехід від общинної до особистої власності і хутірської системи та розселення великих сіл [15, с. 152]. По-друге, проблему малоземельних регіонів Росії пропонувалось вирішити шляхом упровадження протекціоністської політики щодо переселення та купівлі приватної землі. Предметом особливої турботи держави мало стати підвищення купівельної спроможності селян шляхом надання позики в Селянському банку для викупу власних наділів або придбання угідь у межах Європейської Росії, сприяння бажаючим переселитися на вільні казенні землі $[15$, с. 152$]$. У результаті О. Бобринському вдалося схилити більшість делегатів до схвалення запропонованої аграрної програми, що у подальшому була надана на розгляд дворянських зборів, уряду П. А. Столипіна та царю. У доповіді Миколі II О. Бобринський виклав основні засади проекту та обгрунтував її доцільність. Право власності на землю він називав підгрунтям сільськогосподарського прогресу та самодержавного устрою в цілому, застерігаючи про потенційну загрозу переходу до соціалістичного ладу у випадку його руйнації [15, с. 149; 136, с. 138]. Олексій Олександрович переконував у неспроможності політики примусового відчуження припинити селянські заворушення і стабілізувати таким чином ситуацію в країні. Коли приватновласницька земля буде поділена, стверджував він, розпочнеться міжусобна війна через зрівняння надільної землі, і примусове відчуження не тільки не зменшить революційність селян, а навпаки, «розпалить пристрасті» $[15$, с. 151].

Політична тактика О. Бобринського у практичному впровадженні програми аграрної реформи полягала в отриманні підтримки царя, а відтак - здобуття вагомого аргументу впливу на урядові кола. Між ним та прем'єром П. Столипіним були означені межі політичного співробітництва, що полягали у цілковитій підтримці з боку ОД урядового курсу у випадку легітимізації дворянського проекту та домінування «бажаних» представників в урядових структурах. Усвідомлюючи потенційну протидію проведенню запропонованої аграрної реформи з боку інших політичних сил, так і частини селянства, О. Бобринський закликав Миколу II та П. Столипіна до іiї упро- 
вадження у надзвичайному порядку (за ст. 87 Основних законів) [17, с. 137-138]. «В усьому світі - стверджував він, - перехід селян до поліпшених систем господарювання відбувався при сильному тиску зверху» [15, с. 151]. Як результат, ключові пункти програми лягли в основу столипінського курсу в модернізації сільськогосподарського сектору; видання Указу від 9 листопада 1906 р., за яким запроваджувався інститут приватної власності для селян [12], став справжньою політичною перемогою для ОД.

Натхненний першими кроками до співробітництва з П. Столипіним, О. Бобринський виконав зобов'язання щодо підтримки урядової політики. Вже у грудні 1906 р. Постійна рада підготувала доповідь «Про заходи щодо забезпечення особистої і майнової безпеки в селах», де пропонувалось упровадження кримінальної і майнової відповідальності для селян з метою припинення заворушень [7]. «Якби селяни знали, що головних винуватців чекає сувора кара, а всіх учасників - обов'язок компенсувати збитки потерпілим, - підсумовували члени Постійної ради, - то ... нікого було б карати.., тому що розгроми припинилися б самі собою» [7, с. 265].

Запровадження П. Столипіним каральної політики спричинило конфлікт між законодавчою та виконавчою гілками влади. Керівництво Постійної ради відкрито зайняло проурядову позицію: О. Бобринський підтримав розпуск Думи першого скликання, гарантуючи при цьому практичну допомогу у розробці нового проекту виборчого законодавства. 3 цією метою в середині листопада 1906 р. в екстреному порядку був скликаний II з'їзд УДГ, на який прибули представники дворянства від 31 губернії. У представленій на засіданні доповіді про роботу Постійної ради головуючий О. Бобринський окреслив мету засідання: «... Негайно висловити власний погляд на виборчий закон, а також об'єднатися для впливу на майбутні вибори в Держдуму» [7, с. 260]. На чергові докори щодо втручання в урядову політику він упевнено зазначив: «Завдання Постійної ради - критика закону (булигінського. - Прим. моя. - Ч. Н.), а уряду - його вирішення» [13, с. 200-201].

На момент скликання більшість делегатів схилялись до застосування станового принципу у виборчому законодавстві, проте О. Бобринський вніс на розгляд станово-групову схему, підгрунтя якої становило виділення чотирьох груп виборців: селян, великих землевласників, дрібних землевласників і представників міст. У повітах передбачалося виділити особливу групу з дрібних землевласників, в губерніях зрівняти права селян з іншими верствами на- 
селення, а вакантні мандати розподілити між депутатами, обраними iз загальної маси виборців [13, с. 214]. Таким чином, проект, спрямований на формування у Думі потужного дворянсько-землевласницького представництва, був підтриманий переважною більшістю учасників (16 губерній з 21) та наданий царю й уряду [13, с. 215]. Знову ж таки, за підтримки ОД уряд П. Столипіна здійснив відомий «третьочервневий переворот» 1907 р., за яким був введений новий виборчий закон на основі дворянського проекту, а представники ОД, у тому числі й О. Бобринський, отримали бажані важелі політичного впливу на державну політику через парламентські структури влади.

Після отриманих політичних перемог О. Бобринський сподівався на подальшу співпрацю з П. Столипіним у заданому напрямку: розробка законопроектів 3’їздом УДГ та легітимізація з боку уряду. Він покладав на прем'єра великі надії, хоча і не належав до кола його затятих шанувальників. Проте характер діяльності О. Бобринського та ОД в цілому у 1907-1911 pр. був обумовлений політичним дисонансом із П. Столипіним, що знайшов відображення у спрямованості засідань та розходженні між постановами організації та урядовим курсом. Ще в середині березня 1907 р., напередодні скликання III з’їзу УДГ, О. Бобринський довідався про підготовку урядового проекту місцевої реформи і звернувся до прем'єра із проханням надати проект Постійній раді для ознайомлення. Фактично передбачалося, що на засіданнях будуть внесені корективи з метою «попередження сумних для дворянства результатів» [8, с. 317]. Однак П. Столипін не побажав віддати і це питання на розсуд дворянства, хоча й дозволив його обговорення на з'їзді. Тож із початком роботи з'їзду УДГ за пропозицією О. Бобринського була обрана комісія у складі 28 осіб для відпрацювання способів ознайомлення із законопроектом і його обговорення. «Комісія повинна з'ясувати, власне, - говорив він, - що нам можливо зробити в дійсну критичну хвилину» [13, с. 299-300].

Протидія новому законопроекту з боку дворянства була цілком зро-зумілою, виходячи з його змісту. Його підгрунтя становила ліквідація станового управління і створення ланцюга безстанових організацій - сільських, волосних, дільничних, повітових і губернських за майновим принципом [8, с. 38-39]. До складу волості мали увійти не тільки селянські, але й поміщицькі землі, на які відповідно перекладалася частина волосних грошових повинностей. Зберігаючи за повітовим проводирем головування в земських збоpax i землевпорядній комісії, піклування над народними училищами і завідування становими дворянськими справами, інші функції 
перекладалися на посадову особу з такими повноваженнями, якими володів губернатор у масштабі губернії [8, с. 40]. Звідси у заключних постановах III з’їзду УДГ та, відповідно, доповіді О. Бобринського Миколі II висловлювалося невдоволення передачею проекту на обговорення радою у справах місцевого господарства, а не безпосередньо дворянським і земським зборам. Більше того, урядовий проект був визнаний зазіханням на права дворянства і станове підгрунтя самодержавного устрою в цілому [8, с. 102-103].

Активна протидія ОД, що набувала все більшої політичної ваги, змусила П. Столипіна вдатися до компромісних кроків. Підкреслюючи готовність прислухатися до голосу «панівного стану», він ініціював внесення змін до проекту, що дозволяли зберегти певні привілеї дворянства: ідея сільських громад була відкинута, визначений майновий ценз тощо. Проте на IV з'їзді УДГ, що проходив 9-16 березня 1908 р., проект місцевої реформи був підданий справжньому остракізму. О. Бобринський скеровував увагу учасників на питанні безкомпромісного захисту станового принципу і повноважень повітових проводирів дворянства, збереження панівних позицій на селі та в системі управління загалом [13, с. 779-797]. У заключній постанові реформа місцевого управління оголошувалась небажаною, недоцільною і навіть шкідливою, а усунення станових привілеїв дворянства - несумісним із «...турботою про збереження і розвиток монархічного початку» [13, с. 797].

Результати V з'їзду УДГ (17-23 лютого 1909 р.) засвідчили, що ані керівництво, ані учасники не збиралися йти на поступки у питанні місцевого реформування. За пропозицією О. Бобринського на з’їзді відбулось обговорення пакету урядових законопроектів та визначена тактика політичної боротьби представників ОД в парламенті. Учасники підтвердили свою непохитність у відстоюванні прийнятої на тогорічному зібранні платформи. Тож доповідь К. Головіна із викладенням основних засад проекту адміністративної реформи, за висловом О. Бобринського, наочно продемонструвала іiі недоліки та практичну непристосованість [9, арк. 41]. Найбільш важливим моментом проекту було призначення на посаду голови повіту урядового чиновника замість обраного місцевим дворянством повітового проводиря, що підсилювало самостійність бюрократичного апарату. В тому ж напрямку передбачалася заміна земського начальника-дворянина на дільничного начальника без станового цензу [8, с. 41]. Делегати з'їзду висловили неприпустимість об'єднання в одній особі посади начальника повіту і про- 
водиря дворянства, що, на їхню думку, робило останнього залежним від місцевої адміністрації [8, с. 133].

Серед основних перешкод реформі, спрямованій на усунення станових засад, О. Бобринський відзначив розбіжність між сільською поземельною общиною та сільською громадою, неможливість трансформації землеробських селищ у всестанові й звідси - набуття проектованого МВС вигляду міського устрою. Він застерігав, що введення всестанової волості із залученням виборних осіб із правом використання волосного бюджету може призвести до створення нових осередків революційної агітації із залученням місцевого населення. Граф переконував присутніх, що можливість вплинути на загальнодержавні вибори стане могутньою принадою для лівих партій з метою зосередження влади над волосними зборами у своїх руках. «Якщо уряд має на увазі усунути в майбутньому всяку можливість обрання розумної Держдуми і консервативних земств, то запропонована реформа волостей є відмінним засобом досягнення такої мети», - резюмував він [9, арк. 41зв. - 42].

Відзначимо, що радикальна опозиція ОД урядовому курсу у 1907-1911 рр. значною мірою зумовлювалась підтримкою царя. Під час чергової доповіді царю у березні 1909 р. О. Бобринський, запевняючи у непохитності дворянських позицій щодо реформи місцевого врядування, закликав не квапитися з її проведенням. Із метою психологічного тиску на Миколу II він інкримінував проекту обмеження прав верховної влади. У результаті цар пообіцяв не применшувати права повітових проводирів, а протидія повітовій реформі, за твердженням графа, була зустрінута ним співчутливо [5, с. 2; 8, с. 134-135].

Чергові засідання ОД у 1910-1911 pр. проходили в атмосфері антиурядових політичних настроїв; лідер чорносотенців М. Є. Марков заявив, що діяльність дворянських з'їздів «є плодом недовіри уряду» [8, с. 215]. Так, під час роботи VI з'їзду навесні 1910 р. О. Бобринський повідомив присутніх про рішення думської Комісії 3 народної освіти передати головування проводирів дворянства у повітових училищних радах обраним земськими зборами особам. Заздалегідь передбачаючи негативну реакцію на цю пропозицію, він порушив питання, чи вважає дворянство головування своїм корінним правом [14, с. 362]. На засіданні від 16 березня О. Бобринський виступив за поновлення статті в проекті губернської реформи про необхідність губернатора рахуватися з думкою проводиря дворянства та його визнання «першим у губернії охоронцем недоторканності верховних прав самодержавства» [4, с. 404-405]. 
Таким чином, в умовах політичного протистояння з урядом П. Столипіна відбулась трансформація політичної тактики О. Бобринського, а призначення з'їздів УДГ здебільшого полягало у виробленні спільної лінії політичної поведінки його представників у парламенті. Показовим у ефективності використання даної форми політичної боротьби слугував провал урядової реформи місцевого управління.

Отже, суспільно-політична діяльність О. Бобринського у 19061912 рр. була зосереджена на керівництві З’їзом УДГ. Вдале організаційне оформлення, чітке визначення мети та першочергових завдань, особистісний склад, зосередження в руках керівництва широкого кола повноважень обумовили практичну ефективність та вплив ОД на внутрішню політику Російської імперії. Ключові пункти проектів, розроблених під головуванням О. Бобринського, стали підгрунтям відомої столипінської аграрної реформи та «третьочервневого перевороту». Вироблення спільної політичної платформи щодо урядових проектів місцевого реформування призвело до їх провалу в парламенті. За часів головування О. Бобринського ОД набуло значної політичної ваги та фактично стало «кузнею кадрів» для провідних діячів, що перенесли свій політичний потенціал до законодавчих та виконавчих органів влади.

\section{БІБЛІОГРАФІЧНІ ПОСИЛАННЯ}

1. Аврех А. Я. Аграрный вопрос в ІІІ Думе / А. Я. Аврех // Исторические записки / отв. ред. А. Л. Сидоров. - Т. 62. - М.: изд. АН СССР, 1958. - С. 1-57.

2. Аврех А. Я. П. А. Столыпин и судьбы реформ в России / А. Я. Аврех. - М.: Политиздат, 1991. - 286 с.

3. Баринова Е. П. Власть и поместное дворянство в России в начале XX в. : дисс. ... доктора ист. наук: 07.00.02 / Е. П. Баринова. - Самара, 2003. - 409 с.

4. Бородин А. П. Объединенное дворянство и аграрная реформа / А. П. Бородин // Вопросы истории. - 1993. - № 3. - С. 87-109.

5. В Совете объединенного дворянства // Речь. - 17. 03. 1909. - № 74. - С. 2.

6. Дневники Бобринского А. А. с записями о текущих событиях общественно-политической жизни России : в 3 тетр. / 20.09.1910-02.04.1911 г. // Российский государственный архив древних актов (далі - РГАДА). - Ф. 1412. Оп. 8. - Д. 294. - 40 л.

7. Доклад Совета Объединенных дворянских обществ о мерах к обеспечению личной и имущественной безопасности в деревнях // Объединенное дворянство. Съезды уполномоченных губернских дворянских обществ. 1906-1916 гг.: в 3 т. / [сост. А. П. Корелин]. - Т. 1 : 1906-1908 гг. - М.: Российская политическая энциклопедия (РОССПЭН), 2001. - С. 260-271.

8. Дякин В. С. Самодержавие, буржуазия и дворянство в 1907-1911 гг. / В. С. Дякин. - Л.: Наука. Ленинград. отд-е, 1978. - 246 с.

9. Заметки, записки, проекты решений и прочие документы по делам Объединенного дворянства, написанные рукой Бобринского А. А. / 1907-1916 гг. // РГАДА. - Ф. 1412. - Оп. 2. - Д. 352. - 80 л. 
10. Записка Бобринского А. А. Николаю II-му об отношении крестьянства к революции 1905 г. / Черновик. 1908 г. // РГАДА. - Ф. 1412. - Оп. 2. - Д. 703. - 13 л. 11. Наброски речей, заметки, записки, выписки, сделанные рукой Бобринского А. А. по вопросам экономики, с/х, политики, культуры и истории России / Черновики. Т. 1. 1870-1916 гг. // РГАДА. - Ф. 1412. - Оп. 8. - Д. 234. - 120 л.

12. О дополнении некоторых постановлений действующего закона, касающихся крестьянского землевладения и землепользования (Указ от 9 ноября 1906 г.) // Государственная дума в России (в документах и материалах) / сост. Ф. И. Калинычев. - М.: Государственное издательство юридической литературы, 1957. - С. 274-280.

13. Объединенное дворянство. Съезды уполномоченных губернских обществ. 1906-1916 гг.: в 3 т. / [сост. А. П. Корелин]. - М.: Российская политическая энциклопедия (РОССПЭН), 2001-2002. - Т. 1 : 1906-1908 гг. - 2001. - 926 с. 14. Объединенное дворянство. Съезды уполномоченных губернских дворянских обществ. 1906-1916 гг. : в 3 т. / [сост. А. П. Корелин]. - М.: Российская политическая энциклопедия (РОССПЭН), 2001-2002. - Т. 2 : 1909-1912 гг. Кн. 1. 1909-1910 гг. - 2001. - 679 с.

15. Основные положения по аграрному вопросу // Объединенное дворянство. Съезды уполномоченных губернских дворянских обществ. 1906-1916 гг: в 3 т. / [сост. А. П. Корелин]. - Т. 1 : 1906-1908 гг. - М.: Российская политическая энциклопедия (РОС-СПЭН), 2001. - С. 149-152.

16. Особое мнение [А. Н. Брянчанинова] (к журналу заседания 20 марта 1907 г.) // Объединенное дворянство. Съезды уполномоченных губернских дворянских обществ. 1906-1916 гг.: в 3 т. / [сост. А. П. Корелин]. - Т. 1 : 1906-1908 гг. - М.: Российская политическая энциклопедия (РОССПЭН), 2001. - С. 522-523.

17. [Проект всеподданнейшего адреса, подготовленный Постоянным советом] // Объеди-ненное дворянство. Съезды уполномоченных губернских дворянских обществ. 1906-1916 гг.: в 3 т. / [сост. А. П. Корелин]. - Т. 1 : 1906-1908 гг. - М. : Российская политиче-ская энциклопедия (РОССПЭН), 2001. - С. 137-139.

18. Проект организации периодических Съездов уполномоченных губернских дворянских собраний // Объединенное дворянство. Съезды уполномоченных губернских дворянских обществ. 1906-1916 гг. : в 3 т. / [сост. А. П. Корелин]. - Т. 1 : 1906-1908 гг. - М.: Российская политическая энциклопедия (РОССПЭН), 2001. - С. 146-147.

19. Речь кандидата в депутаты I Гос. думы Бобринского А. А. (монархиста) своим избирателям по Адмиралтейскому участку с изложением своей программы политических взглядов и убеждений / 1905-1906 гг. // РГАДА. - Ф. 1412. Оп. 2. - Д. 176. -39 л.

20. Соловьев Ю. Б. Самодержавие и дворянство в 1902-1907 гг. / Ю. Б. Соловьев. - Л.: Наука. Ленинград. отделение, 1981. - 256 с.

21. Соловьев Ю. Б. Самодержавие и дворянство в 1907-1914 гг. / Ю. Б. Соловьев. - Л.: Наука. Ленинград. отделение, 1990. - 267 с.

22. Устав Съездов уполномоченных Объединенных дворянских обществ // Объединенное дворянство. Съезды уполномоченных губернских дворянских обществ. 1906-1916 гг.: в 3 т. / [сост. А. П. Корелин]. - Т. 1 : 1906-1908 гг. - М. : Российская политическая энциклопедия (РОССПЭН), 2001. - С. 520-522.

23. Чернікова Н. С. Суспільно-політична та державна діяльність графа Олексія Олександровича Бобринського: автореф. дис. ... канд. іст. наук : 07.00.02 / Н. С. Чернікова. - Дніпропетровськ: Вид. «Інновація», 2012. - 23 с

Надійшла до редкол.: 12.03. 2018 